\title{
Analysis of structural changes and phase transformations in Sikhote- Alin IIAB iron meteorite under various origin shock deformation
}

\author{
R. F. Muftakhetdinova , V. I. Grokhovsky, G. A. Yakovlev \\ ${ }^{\dagger}$ gizrozka91@bk.ru
}

Ural Federal University, Mira St. 19, Yekaterinburg, 620002, Russia

\begin{abstract}
A comparative analysis of structural and phase transformations in the Sikhote-Alin meteorite with different shock prehistory has been done: shards from the impact crater, conditionally unstressed individual fragments and samples after model experiments on spherically converging shock waves loading. This meteorite belongs to the class of coarse octahedrites, and Fe-Ni-Co alloy with P, S and N impurities. Techniques of optical and scanning electron microscopy with energy dispersive X-ray spectrometry (EDS) and electron backscatter diffraction (EBSD) analysis units have been used for provided information on temperature and deformation changes in extraterrestrial matter in case of impact of space and terrestrial conditions, as well as in case of shockwave loading. The formation of specific structural elements of deformation in shards of meteoritical substance from an impact crater was observed: curved Neumann lines, fibrous structure, regions of localized flow in the alpha-phase kamacite $\mathrm{Fe}(\mathrm{Ni}, \mathrm{Co})$ and traces of brittle localized destruction of rod-shaped phosphides $(\mathrm{Fe}, \mathrm{Ni})_{3} \mathrm{P}$. Analysis of the behavior of an extraterrestrial substance during model explosive loading gave an opportunity to match microstructural changes occurring in the meteorite substance and factors accompanying shock-wave action. Localized flows and traces of ductile fracture of thin roaldite plates $(\mathrm{FeNi})_{4} \mathrm{~N}$ have been observed. Intensive generation of new twins in the near-surface zone of samples due to localization of deformation and increase of local pressure up to $20 \mathrm{GPa}$ was detected. Systematization of structural and phase changes in an inhomogeneous substance of Sikhote-Alin meteorite depending on the intensity of the shock wave effects has been suggested.
\end{abstract}

Keywords: meteorite, Fi-Ni alloys, deformation, shock waves.

УДК: $534.222 .2+536.4$

\section{Анализ структурных изменений и фазовых превращений в железном метеорите Сихотэ-Алинь (IIAB) под действием ударной деформации различной природы}

\author{
Муфтахетдинова Р. Ф. ${ }^{\dagger}$, Гроховский В. И., Яковлев Г. А. \\ Уральский федеральный университет, ул. Мира, 19, Екатеринбург, 620002, Россия
}

Проведен сравнительный анализ структурных изменений и фазовых превращений в веществе метеорита СихотэАлинь с разной ударной предысторией: осколочных фрагментах из ударного кратера, претерпевших деформационное воздействие во время удара о Землю, условно неударенных индивидуальных фрагментах и образцах после модельных экспериментов по нагружению сферически сходящимися ударными волнами. Исследуемый метеорит относится к классу грубоструктурных октаэдритов (IIAB), представляющих собой сплав Fe-Ni-Co с примесями P, S, N. Методами оптической и растровой электронной микроскопии с возможностью локального рентгеноспектрального анализа (EDS) и дифракции обратно-отраженных электронов (EBSD) изучены температурные и деформационные изменения в веществе внеземного происхождения при воздействии космических и земных условий, а также модельного ударно-волнового нагружения. Установлено образование специфических структурных элементов деформации в осколочных фрагментах вещества метеорита из ударного кратера: изогнутых линии Неймана, волокнистой структуры и областей локализованного течения материала в матричной альфа-фазе камасите $\mathrm{Fi}(\mathrm{Ni}, \mathrm{Co})$ и следы хрупкого локализованного разрушения стержневидных фосфидов $(\mathrm{Fe}, \mathrm{Ni})_{3}$ Р. Анализ поведения вещества внеземного происхождения при модельном взрывном нагружении позволил сопоставить микроструктурные изменения, происходящие в веществе метеорита и факторы, сопровождающие ударно-волновое воздействие. В областях сильной локализованной деформации в матричной альфа-фазе $\mathrm{Fi}(\mathrm{Ni}, \mathrm{Co})$ наблюдали участки локализованного течения и следы вязкого разрушения тонких пластин роалдита $(\mathrm{FeNi})_{4} \mathrm{~N}$. В приповерхностных зонах образцов, вследствие локализации деформации и локального повышения давления до 20 ГПа и более, обнаружена интенсивная генерация новых двойников. В заключении работы предложена систематизация структурных и фазовых изменений в неоднородном веществе железного метеорита Сихотэ-Алинь в зависимости от интенсивности ударно-волнового воздействия космических и земных условий, а также модельного взрывного нагружения.

Ключевые слова: метеорит, Fi-Ni сплавы, деформация, ударные волны. 


\section{Introduction}

It is impossible to obtain a complete picture of the evolution of the Solar System without an understanding of shock processes. Throughout the history of the Solar System, small bodies have repeatedly collided with each other, as well as with planets. Thus, any cosmic substance for its existence undergoes at least one shock event, which is accompanied by high pressures and temperatures. Usually, shock waves are characterized by the instantaneous increasing of pressures (up to megabars) and temperatures (up to 10,000 degrees or more) at pressure relief. Such processes result in a change in the structure of meteorite minerals.

Processes occurring in minerals, including meteoritic matter, under the influence of shock waves began to be studied from the middle of the twentieth century. Semiquantitative scale for shock classification of chondrites is well known. A generalization of these works one can found in the scientific works of D. Stoffler [1,2,3].

A significant amount of literature data on deformation changes and polymorphic transitions in shockwave loading in metals, minerals, and rocks relates to homogeneous materials [4-14]. Information on complex phase transformations in such multiphase objects as meteorites is not numerous and therefore causes even greater interest among researchers. The propagation of shock waves in a heterogeneous material, such as a meteorite, is an extremely complex process. The distribution of temperatures and pressures in meteoritic matter is very chaotic. For example, in ordinary chondrites with a grain size of about a millimeter, the pressure reaches equilibrium in the course of microseconds after the impact, and several seconds are needed to reach the equilibrium temperature [15]. Laboratory shockwave loading experiments make it possible to study deformation phenomena and polymorphic transformations in a material with the simultaneous action of several factors: high-speed deformation, ultrahigh pressures, and elevated temperatures [4-11, 13-16].

Features of the meteorites structure formation are determined by the influence of cosmic vacuum, low temperatures, extremely slow cooling rate $\left(1^{\circ} /\right.$ million years), thermal, impact (up to $300 \mathrm{GPa}$ ), high-speed deformation (up to $10^{7} \mathrm{~s}^{-1}$ ) and other extreme effects. Investigation of these features makes it possible to obtain information on microstructural changes in iron alloys and iron-containing minerals of meteoritic origin, probably caused by various conditions of their formation [3, 12]. Such approach can be useful for analyzing the thermal and shock history of extraterrestrial matter and for modeling the processes of formation of the solar system. Structural changes induced by the action of shock waves are considered at three levels: macroscopic, mesoscopic and microscopic. The study of macrostructure provides important information about propagation, interaction of convergent shock waves and the final stages of localized destruction. Mesoscale observation allows one to research phenomena of localized deformation (different types of flow, bands of adiabatic shear, etc.) in volumes that cover large groups of grains (up to several millimeters). Processes of formation of deformation dislocation, twin structures and phase transformations caused by the action of shock waves are studied at microscale $[1-3,8]$.

The structure of iron meteorites after impact loading has been studied in many papers, but a clear classification of structural changes has not been suggested. An absence of such classification can be explained by significant variations in the initial structure of iron meteorites and by their structural changes after impacts. In this work, we consider the processes occurring in meteorite minerals in case of shock loading in outer space, during their falling on the Earth's surface and during shock loading experiments.

The initial structure of the Sikhote-Alin iron meteorite (IIAB) containing 5-7 wt \% Ni was studied earlier in $[8,9]$, where it was found that the meteorite material experienced shock-wave loading when it entered the dense layers of the Earth atmosphere and fell on the ground. Study of individual fragments of the Sikhote-Alin meteorite using optical and electron microscopy techniques revealed the presence of uniformly distributed dislocations, dislocation loops, cellular dislocation substructure, deformation microtwins. Traces of the phase transformation $\alpha \rightarrow \varepsilon \rightarrow \alpha$ in microstructure of these samples weren't found. Hence, the highest pressure in these samples (before fall and during contact with surface) did not exceed $12 \mathrm{GPa}$. In addition, it was established that the adiabatic heating under shock loading did not exceed $350-400^{\circ} \mathrm{C}$. In particular, the features of the formation of a contact-melting structure on the interface between on kamacite $\alpha(\mathrm{Fe}(\mathrm{Ni}, \mathrm{Co}))$ and rhabdite $\left.(\mathrm{Fe}, \mathrm{Ni})_{3} \mathrm{P}\right)$ of SikhoteAlin iron meteorite due to a local increase in temperature and pressure under spherical loading converging shock waves are studied in detail in [17].

The aim of this work is a study of shock metamorphism features at individual fragments and shards of Sikhote-Alin iron meteorite, which were formed during impacts of parent bodies in space and after fall to the Earth. Comparison of acquired data with structural changes in shock-loaded sample from the same meteorite is another goal of this research. Such approach allows to systemize structural and phase transformations in iron meteorites subjected to shock influence of various intensity and origin.

\section{Samples and methods}

The substance of iron meteorite Sikhote-Alin is of particular interest to researchers, since it belongs to the number of unique phenomena of nature - the Sikhote-Alin meteorite shower. Bolide was observed on February 12, 1947 at 10:38 am. over the Ussuri taiga (Russia, Primorsky Krai). Tens of thousands of fragments were found with total mass more than 31 tons. The largest undefeated specimen weighs $1745 \mathrm{~kg}$. The Sikhote-Alin meteorite is classified as coarsestructured octahedrite, chemical group IIAB.

The Sikhote-Alin iron meteorite (IIAB) is a coarse octahedrite with the following average chemical composition: $\mathrm{Ni}-5.94 \%$, Co $-0.38 \%, \mathrm{Cu}-0.03 \%, \mathrm{P}-0.48 \%, \mathrm{~S}<0.28 \%$, $\mathrm{Fe}$ - balance. Wide single-crystal bands of $\alpha$-Fe (Ni, Co) contain a different dispersity of rhabdites $(\mathrm{Fe}, \mathrm{Ni})_{3} \mathrm{P}$. Massive inclusions of troilite and shreibersite occur at the kamacite bands boundaries [12]. Also, this meteorite is of interest due to crater formation and existence of shards from this 
impact crater and relatively undeformed matter as individual fragments.

For the study were selected are fragments of the SikhoteAlin meteorite with different shock prehistory: relatively unshocked individual fragments, samples from the impact crater and samples subjected to action of converging shock waves. Explosive experiments with the preservation of compressed samples of the Sikhote-Alin meteorite were carried out at RFNC-VNIITF (Snezhinsk) [8,16,17]. After shock-wave loading, the samples were cut in half for structural analysis. The structure was studied on polished sections prepared using standard techniques after etching in a $2-4$ vol $\% \mathrm{HNO}_{3}$ solution in ethyl alcohol. Microstructure analysis was carried out on the certified equipment of the NANOTECH Center at the Ural Federal University, viz., inverted reflection microscope Carl Zeiss Axiovert 40 MAT and scanning electron microscope Carl Zeiss Ligma VP with a energy-dispersive X-ray spectrometer INCA Energy (EDS) and Nordlys detector of electron backscatter diffraction by HKL (EBSD).

\section{Results and discussion}

Fragments from the Sikhote-Alin impact craters demonstrate external signs of plastic deformation - pointed ragged edges and the absence of melting crust (Fig. 1). These samples were collected by members of Meteoritical expedition of Ural Federal University (field season 1997) at ejecta rim of the biggest crater.

In these samples traces of complete or partial remelting of the minerals weren't detected. In the peripheral part of the fragments from the impact crater, a fibrous pattern (fibrous texture) is observed, which was formed due to the flow of metal as a result of plastic deformation. Individual fibers in the form of the fine tape-like interlayers contain finely dispersed phosphides (Fig. 2a,2b). Such phenomenon was described earlier in [18].

Brittle fracture of rod-like rhabdites (Fig. 3) are observed at a distance from the surface of samples. However, central part of the sample remains unchanged initial microstructure, where one can find boundaries of the kamacite bands decorated with phosphides.

Various traces of shock metamorphism in the SikhoteAlin meteorite after shock waves loading were observed. Also, traces of local plastic deformation (Fig. 4a) and localized fracture has been found. Brittle fracture traces in rod-like rhabdites $(\mathrm{FeNi})_{3} \mathrm{P}$ are well distinguished (Fig. $4 \mathrm{~b}$ ). The viscous nature of deformations is well visible in case of shear passes through thin roaldite $(\mathrm{FeNi})_{4} \mathrm{~N}$ plates (Fig. $4 \mathrm{c}$ ). Moreover, an increase in the dislocation density in kamacite, deformation by sliding and twinning (Fig. 4d), evidence of reaching $\gamma$-region of Fe-Ni diagram, contact melting at the kamacite-rhabdite boundary, regions of complete remelting of phosphides and traces of $\alpha \rightarrow \varepsilon \rightarrow \alpha$ transformations were observed [19]. Results of contact melting phenomenon research are discussed in [17] in details. All this indicates that during the experimental loading, in some zones the pressure was significantly higher than $13 \mathrm{GPa}[16,17,20,21]$, and temperature at the interphase boundaries reached $900^{\circ} \mathrm{C}$. Such situation with change of $\varepsilon$-phase has been observed in

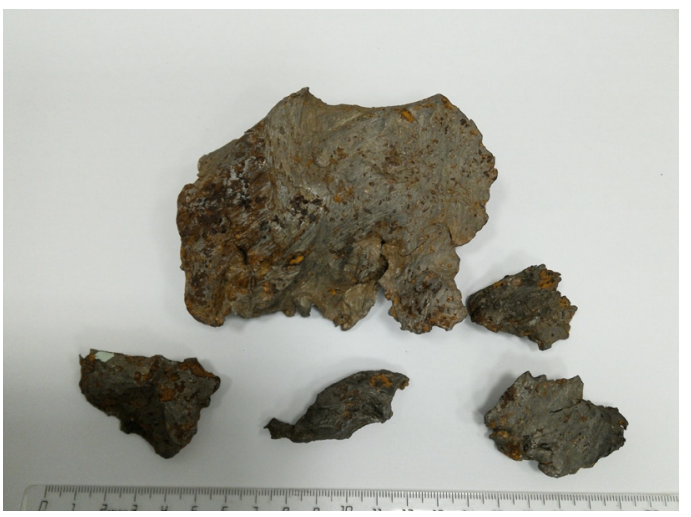

Fig. 1. Pieces of Sikhote-Alin meteorite from impact crater.
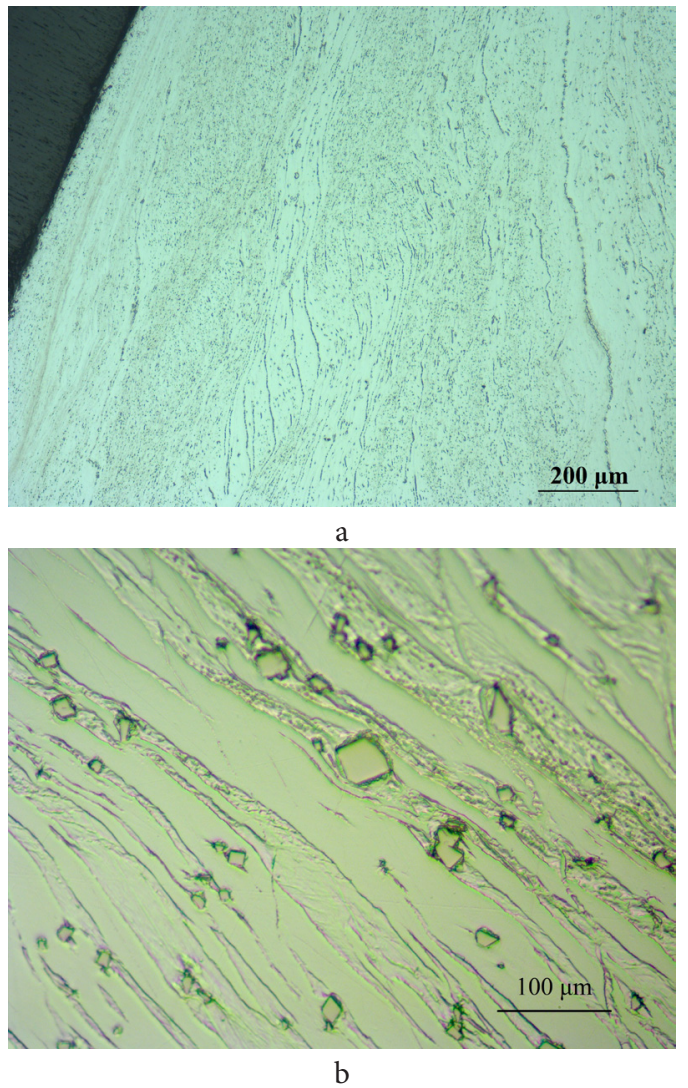

Fig. 2. (Color online) Fibrous texture in piece of Sikhote-Alin meteorite (a), Fibrous texture with ribbon-like interlayers containing finely dispersed phosphides of Sikhote-Alin meteorite from impact crater (b).

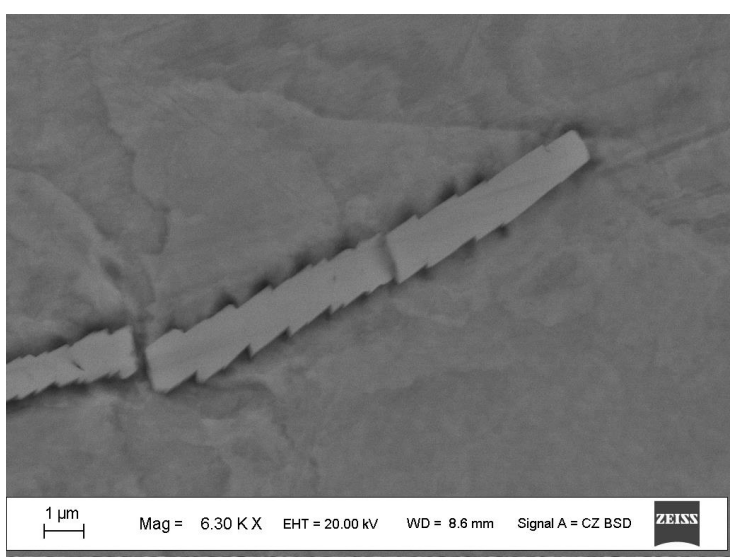

Fig. 3. Brittle fracture of rod-like rhabdites in piece of Sikhote-Alin meteorite from impact crater. 


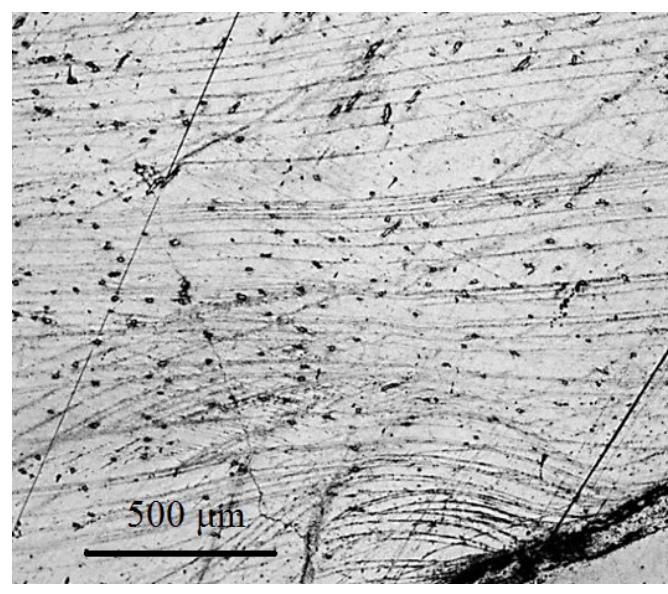

a

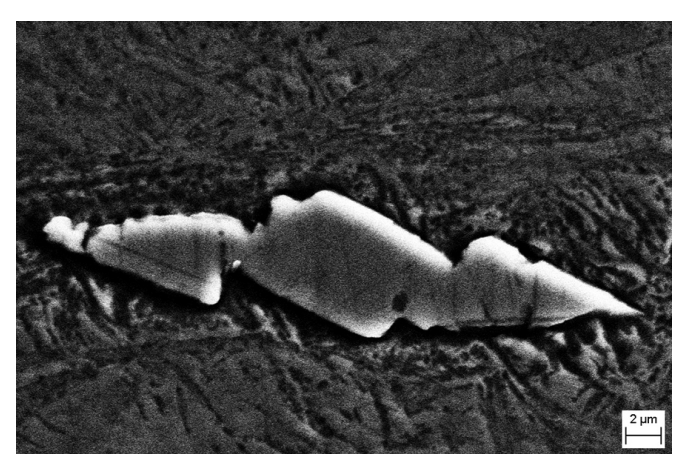

$\mathrm{b}$

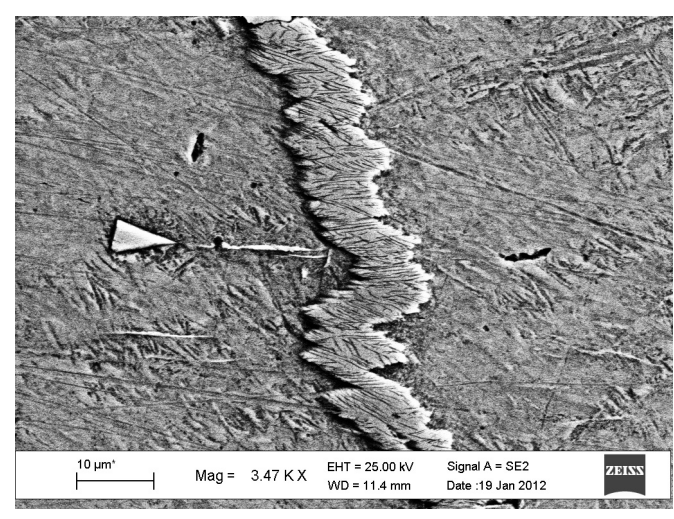

C

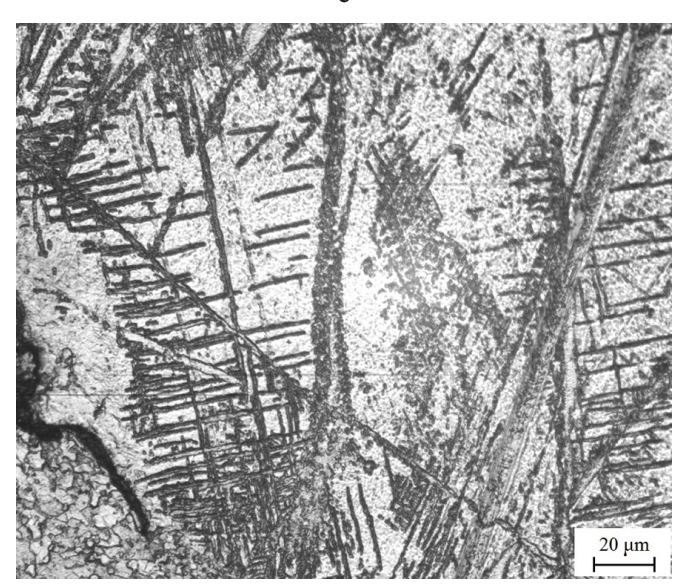

d

Fig. 4. Structural changes in meteorite after action of converging shock waves (pressure <12 GPa): distortion of Neumann bands (a), brittle fracture of rhabdite $(\mathrm{FeNi})_{3} \mathrm{P}(\mathrm{b})$, shear passing through thin roaldite $(\mathrm{FeNi}){ }_{4} \mathrm{~N}$ plates $(\mathrm{c})$, deformation twins in $\alpha$-phase $\mathrm{Fe}$ $(\mathrm{Ni}, \mathrm{Co})(\mathrm{d})$.
[22] in case of explosive loading of hollow cylinders from steel $12 \mathrm{X} 18 \mathrm{H} 10 \mathrm{~T}$ with $4,5 \mathrm{GPa}$ and $20 \mathrm{GPa}$ pressure. Formation of high pressure phase at iron-nickel alloys was discussed earlier in $[10,11]$. In addition to changing the microstructure, shock loading increases the hardness of the meteorite material, and the increase in hardness is almost proportional to the increase in pressure upon impact.

\section{Conclusions}

A lot of work has been devoted to the problem of shock metamorphism of iron meteorites. After the studies and analysis of the literature data, the following conclusion can be drawn: due to the complex structure of iron meteorites, formed as a result of various types of shock-wave influences in space and terrestrial conditions, as well as model explosive loading, it is very difficult to compile a detailed classification of the structural features of this class of meteorites However, it is possible to highlight the main types of structural changes. When the pressure is below $0.7 \mathrm{GPa}$, the dislocation density increases. In the pressure range between 0.7 and $13 \mathrm{GPa}$, deformation twinning is observed in addition to the formation of dislocations, and the twin density increases with increasing shock pressure. Phase transformation of the cubic $\alpha$-phase into a more tightly packed hexagonal $\varepsilon$-phase is the next stage of matter alteration, which happens when pressure exceed $13 \mathrm{GPa}$. Withdrawal of loading causes a phase transformation $\varepsilon \rightarrow \alpha$. In addition to changing the microstructure, shock loading increases the hardness of the meteorite material, and the increase in hardness is almost proportional to the increase in pressure upon impact. It was established, that in the individual fragments of the SikhoteAlin meteorite the pressure amplitude did not exceed $12 \mathrm{GPa}$ during entering the dense layers of the atmosphere and falling to Earth. Fragments from impact craters underwent inhomogeneous plastic deformation, most noticeable in the peripheral part of the fragments.

Acknowledgements. This work was supported in part by the Ministry of Education and Science of the Russian Federation (The projects 5.4825.2017/6.7, 5.3451.2017/4.6) and the Act 211 of the Government of the Russian Federation.

\section{References}

1. D. Stöffler. Fortsch. Mineral. 49, 50 - 113 (1972).

2. D. Stöfer, A. Bischoff, V. Buchwald, and A.E. Rubin. In: Meteorites and the Early Solar System, ed. by J. F. Kerridge and M.S. Matthews, Univ. of Arizona, Tucson (1988). P. $165-202$.

3. D. Stöffler, K. Keil, and E.R. D. Scott. Geochim. Cosmochim. Acta. 55, 3845- 3867 (1991).

4. Shock Waves and High-Strain-Rate Phenomena in Metals (Eds. by M. A. Meyers, L.E. Murr). Plenum Press, USA (1981). $512 \mathrm{p}$.

5. E. A. Kozlov, B. V. Litvinov, E.V. Abakshin, A.V. Dobromyslov, N.I. Talutz, N.V. Kazantseva, G. G. Taluts. The Physics of Metals and Metallography. 79 (6), 113-127 (1995) (in Russian) [Е.А. Козлов, Б.В. Литвинов, Е.В. Абакшин, А.В. Добромыслов, 
Н.И. Талуц, Н.В. Казанцева, Г.Г. Талуц. Физика Металлов и Металловедение. 79 (6), 113 - 127 (1995)].

6. C.M. Fowler, F.S. Minshall, T.G. Zukas. In: Response of Metals to High Velocity Deformation, ed. by P.G. Shewmon and V.F. Zackay New York, USA, Interscience Publishers Inc., (1960). P. 275 - 308.

7. V.I.Zeldovich,I. V.Khomskaya,A. A.Deribas,A. N.Kiselev. Phys. Metals and Metallogr. 60 (1), $101-108$ (1985) (in Russian) [В. И. Зельдович, И. В. Хомская, А. А. Дерибас, А.Н. Киселев. ФММ. 60 (1), $101-108$ (1985)].

8. E. A. Kozlov, V.A. Teplov, M.S. Kuzina, V. I. Grokhovsky. Abst. XXXII Lunar and Planetary Science Conf. (LPSC2001). Houston, USA. (2001) p. 1057.

9. V. I. Grokhovsky, E. A. Kozlov, L. E. Kar'kina, V. A. Teplov. Phys. Metals and Metallogr. 91 (3), $72-80$ (2001). (in Rusian) [В. И. Гроховский, Е. А. Козлов, Л.Е. Карькина, В. А. Теплов. ФММ. 91 (3), 72 - 80 (2001).]

10. V.I. Zel'dovich, I. V. Khomskaya, N.Yu. Frolova, A.E. Kheifets, V.M. Gundyrev, B.V. Litvinov. AIP Conference Proceedings, 849, 62-67 (2006).

11. I. V. Khomskaya. Perspektivnye materialy. 12, 551-558 (2011) (in Rusian) [И.В. Хомская. Перспективные материалы. 12, 551 - 558 (2011)].

12. V.F. Buchwald. Handbook of Iron Meteorites. Their History, Distribution, Composition and Structure. Unif. California Press, USA (1975) 1418 p.

13. H.G. Bowden, P.M. Kelly. Acta Metallurgica. 15 (9), 1489 - 1500 (1967).

14. P. M. Giles, M.N. Longebach, A.R. Marder. Journal of Applied Physics. 42 (11), 4290 - 4295 (1971).
15. T. G. Sharp, P. S. de Carli. Meteorites and the Early Solar System, Tucson, USA, University of Arizona Press, (2006). P. 905 (653 - 677).

16. R.F. Muftakhetdinova, V.I. Grokhovsky, E. A. Kozlov, I. V. Khomskaya, \& G.A. Yakovlev. Technical Physics. 61 (12), $1830-1834$ (2016). (in Russian) [Р. Ф. Муфтахетдинова, В. И. Гроховский, Е.А. Козлов, И.В. Хомская, Г.А. Яковлев. ЖТФ, 86 (12), $73-77$ (2016), DOI:10.1134/S1063784216120239.

17. R.F. Muftakhetdinova, V.I. Grokhovsky, G. A. Yakovlev, E. A. Kozlov, A. A. Degterev. Letters on Materials. 5 (1), 110 - 114 (2015). (in Russian) [Р.Ф. Муфтахетдинова, В.И. Гроховский, Г.А. Яковлев, Е.А. Козлов, А. А. Дегтярев. Письма о материалах. 5 (1), 110 - 114 (2015).]. DOI: 10.22226/2410-3535-2015-1-110-114

18. R. I. Mintz, T.M. Petukhova, V..P Shaldybin. Metallurgy and heat treatment of metals. 3, 7-9 (1978) (in Russian) [Р.И. Минц, Т.М. Петухова, В.П. Шалдыбин. Металловедение и термическая обработка металлов. 3, $7-9$ (1978)].

19. S. J. Wang, M. L. Sui, Y. T. Chen et al. Sci. Report, 3 (2013). 20. R.F. Gizzatullina, V.I. Grokhovsky, G.A. Yakovlev. Meteoritics \& Planetary Science. 49, A137 (2014).

21. R.F. Muftakhetdinova, V.I. Grokhovsky. Meteoritics \& Planetary Science. 52, 6005 (2017).

22. L. N. Okley, I. V. Chkhartishvilli. Structure of metals under high pressure. Moscow, Metallurgy (1990) 144 p. (in Russian) [Оклей Л.Н., Чхартишвилли И.В. Структура металлов при воздействии высоких давлений. - M.: Металлургия (1989) 116c]. 